\title{
Mechano-sorptive creep of Portuguese pinewood chemically modified
}

\author{
Duarte Barroso Lopes ${ }^{1,2} \bowtie$, Carsten Mai ${ }^{2}$ \\ ${ }^{1}$ School of Engineering - Polytechnic of Porto, Rua Dr. António Bernardino de Almeida 431, 4200-072 Porto, Portugal, \\ phone: +351228340500 , fax: +351228321159 , e-mail: dbl@isep.ipp.pt \\ ${ }^{2}$ Wood Biology and Wood Products, Büsgenweg 4 - 37077, Germany
}

\section{SUMMARY}

The effect of chemical modification on mechano-sorptive creep in bending was studied by experimental work. Stakes with $20 \times 20 \times 400 \mathrm{~mm}$ RTL of Portuguese wood species (Pinus pinaster Aiton) modified with 1,3-dimethylol-4,5dihydroxyethyleneurea (DMDHEU), m-methylated melamine resin (MMF), tetraethoxysilane (TEOS) and amid wax (WA) were measured under asymmetric moistening conditions over a period of 42 days (app. 1000 hours) with stress level (SL) of $12 \mathrm{MPa}$, according to ENV 1156.

The cell wall treatments (DMDHEU and MMF resins) had shown significant reduction of creep (creep factors, $\mathrm{k}_{\mathrm{c}}$ ) when compared to untreated wood under similar conditions. Both types of resins and levels of treatments (different WPG) did not shown significant effects.

In the lumen fill treatments, deposit material of TEOS did not affected the creep behaviour $\left(\mathrm{k}_{\mathrm{c}}\right)$; Wax treatment was shown a particular compliance of creep due to avoid exchange moisture (by the hydrophobic effect of wax).

The anti-creep efficiency (ACE) correlated better than other mechanical or physical properties imparted by the modification process.

\section{KEY WORDS}

admid wax, bending creep, creep factor, mechano-sorptive effect, Pinus pinaster, resins

\section{INTRODUCTION}

The creep propensity is an important quality parameter for wood used as load-bearing material in building constructions. The wood-moisture interaction has a decisive role on the behaviour of a horizontal member in loaded condition, where long-term deformation occurs. The mechano-sorptive effect (MSE) is an amplification of the elastic deformation and an acceleration of the visco-elastic strain rate.
Over the last years an extensive work on quantifying and predicting creep behaviour has been undertaken: in untreated wood (Hoffmeyer and Davidson 1989; Morlier 1994; Bengtsson 2001; Hunt 2004), wood products (Dinwoodie et al. 1981; 1984; 1990; 1991a; 1991b; 1992) and modified wood (Norimoto et al. 1992; Epmeier and Kliger 2005). In the latter's, some of the most important parameters and characteristics of mechanosorptive behaviour are as follows: 
- Treatments with cell wall reaction (especially resin based) had good relation with moisture-change. They assumed the best performance under the creep of MSE.

- Modification of the cell wall at the molecular level (and not filling the cell-wall cavities alone) was required to affect the MSE.

- The effect of chemical modification on the MSE of wood creep can be characterized by a factor named anti-creep efficiency (ACE) which has a good correlation with anti-swelling efficiency (ASE).

Creep results might be affected by different variables: tree rings width, provenance material in the tree and stem, close to the pith or to the bark (Bengtsson 2000, 2001), modulus of elasticity (MOE), ratio volume and cross section area (V/A), environment temperature (Green and Evans 2008), historical load (due to the cumulative effect), drying type (Hanhijärvi 1999) and moisture content (MC) (Hering and Niemz 2011). The wood material heterogeneity does not allow different variables of material to reflect alone on the creep results. However, it's unanimously accepted that the wetting and dry changes of wood material is the highest amplifier of the creep deformation (Norimoto et al. 1992; Bengtsson 2000; Hunt 2004; Epmeier et al. 2005).

Logsdon (1998) studied separately the compression and tension strength behaviour with different range of $\mathrm{MC}$, indoor up to fibre saturation conditions. While the compression strength showed a reduction up to $80 \%$, tensile stress reduced up to $40 \%$ (comparatively, fifty percent less). Bengtsson (2000) had showed larger creep effect in compression than in tension under unidirectional MSE of untreated pinewood.

Under asymmetric moistening conditions in bending, compression zone showed larger deformation than in tension wet, at indoor creep or mechano-sorptive conditions, respectively by Moliński and Raczkowski (1988) and Roszyk (2005).

This study was conducted in bending under asymmetric moistening conditions, with compression and tension zone. The reasons to support this decision were related to the enhancement of mechanical properties imparted by the chemical modification and practical applications, briefly described as follows:

- Treatments with good relation with moistening (Pfeffer 2011), the cell wall reaction treatments (DMDHEU and MMF resin) had shown significant in- creasing on the compression strength and decreased in the tension strength in different extend (Bollmus et al. 2009).

- Bearing elements working in the so-called semiopen space, condensed water vapour falling on wooden materials and leaking roofs leading to seepage on rafter framing are practical examples to pursue this study.

The objective of this work is to study the mechano-sorptive creep behaviour in bending of Portuguese modified pinewood under asymmetric conditions of moistening.

\section{MATERIAL AND MEtHOdS}

Four methods of chemical modification were investigated: 1,3-dimethylol-4,5-dihydroxyethyleneurea (DMDHEU), N-methylol melamine (MMF), tetra-alkoxysilane (TEOS) and amid wax (WA).

The specimens were dried for $24 \mathrm{~h}$ at $103^{\circ} \mathrm{C}$ and then impregnated with different solutions. A full cell process with a vacuum step of 30 min followed by $2 \mathrm{~h}$ pressure step at 12 bar were used.

Impregnations with aqueous solutions of DMDHEU supplied by BASF (Ludwigshafen, Germany) were performed in the following concentrations: $1.3 \mathrm{M}$ and $2.3 \mathrm{M}$ using $4 \%$ magnesium nitrate relative to the mass of DMDHEU of the solution as catalyst. Two levels of modification with DMDHEU resin are referred as D1 and D2.

$\mathrm{N}$-methylol-melamine formaldehyde (MMF) was Madurit MW 840 supplied by INEOS (Frankfurt a. M., Germany). The original resin/water solution had $75 \%$ of concentration. To obtain two levels of concentrations (15 and 30\%) it was diluted with water. After impregnation, specimens were dried for $48 \mathrm{~h}$ at room temperature. For resin curing, wood material was stored four days in an oven with 5 steps of temperature. Until reach $90^{\circ} \mathrm{C}$, the temperature increase $10^{\circ} \mathrm{C}$ every day. Two levels of modification with MMF resin are referred to hereinafter as i1 and i2.

TEOS was applied in sol state as described by Donath et al. (2004). Ethanol (1 mol) was added to $1 \mathrm{~mol}$ and stirred at ambient temperature for $30 \mathrm{~min}$. After the impregnation, specimens were cured in an oven at $60^{\circ} \mathrm{C}$ for 4 days. TEOS treatment is abbreviated as T. 
A synthetic amid wax in hot melting state was used. The wax was impregnated at temperature of $120^{\circ} \mathrm{C}$ in liquid state. The modification with amid wax is abbreviated as WA.

Additional information about treatments used in this study can be found in different works, Militz (1993); Epmeier et al. (2004); Donath et al. (2004) and Scholz et al. (2009), respectively.

All works were made using Portuguese maritime pine specie (Pinus pinaster Aiton) with pure sapwood part of the stem. Specimens were cut carefully, so that each one would contain the same annual rings and would be exactly straight-grained with dimensions $20 \times 20 \times 400 \mathrm{~mm}$ RTL resulting in a total of 129 specimens, i.e. 31 controls and 98 modified specimens.

Density of the tested wood was determined at indoor conditions of moisture content (RH 50\%) before modification, was within the range of 520 to $550 \mathrm{~kg} / \mathrm{m}^{3}$. The orientation of the growth rings of wood specimens was parallel to its faces and perpendicular to the support. The width of annual rings was about $3 \mathrm{~mm}$ on tile average, see grey lines in fig. 1B.

The load was applied in a four-point bending system (4 pb) according to EN 408 and ENV 1156, fig. 1A. Supports were spaced at $360 \mathrm{~mm}$ and loading blocks $(16 \mathrm{~kg} / 157 \mathrm{~N})$ were spaced at $180 \mathrm{~mm}$ and selected in such a way to ensure constant loading with $12 \mathrm{~N} / \mathrm{mm}^{2}$ in bending stress $(» 12 \%$ of modulus of rupture for untreated wood, MOR).

Two moistening process were applied separately, see fig. 1A. In the first case, moistening was carried out on the upper compression stress side. In the second one, the tensioned fibres were as well in the upper side. In this case, the support and load-shoes positions were changed.
The moistening was achieved by fixing strip filter paper to the radial surface, on top of the specimen, stretched in the middle part of $180 \mathrm{~mm}$ (between loadshoes) and whose ends were dipping into a container to adsorb water by capillarity (over 5 hours long). The moistening processes were initiated after seven days/ first week of loading and repeated every week until 5 cycles were reached (42 days $/ 1000$ hours).

Twenty millilitres of distilled water with 5 hours of expositions in the upper radial surface of the specimens were used. This environment conditions are similar to the Mediterranean climate in the southern Europe, moistening variation by a downpour and the remaining weeks with low RH happened very often.

The length of the cycle was defined with a preliminary evaluation of moisture content (MC). Unloaded specimens under similar conditions of moistening as the creep test were used. Afterwards, the moisture content was measured at different times with a Protimeter Moisture Measurement System (Instruction Manual Protimeter 2005). Two pins were pressed against to the tangential surface of wood specimen with few millimetres $(2-3 \mathrm{~mm})$ of penetration. After few seconds, the $\mathrm{MC}$ was obtained in 3 depth, according to fig. 1B. The average of both sides of the cross section was taken.

Tension and compression strength in the longitudinal direction were performed on a Zwick/Roel ZMART. PRO $100 \mathrm{kN}$ test machine (Ulm, Germany).

Table 1 shows a summarized an overview of different properties, specimens sizes and applied standards followed in the experimental work.

Dynamic $\mathrm{MOE}_{\text {dyn }}$ tests were carried out using the impulse vibration technique. The specimens were placed on foam rubber to simulate the free-free condition with respect to axial vibration $(0.224 \cdot 1$, where 1 is
A

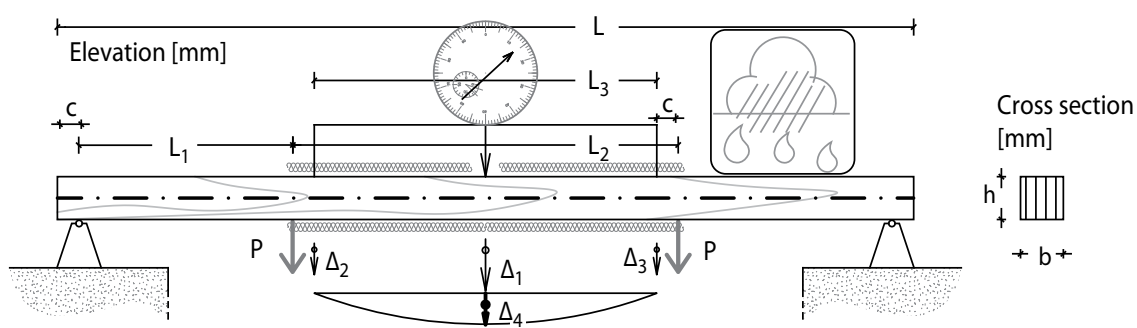

B

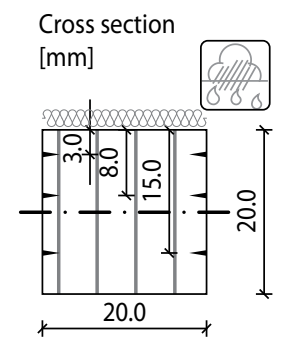

Fig. 1. A - Load and moistening arrangement for $20 \cdot 20 \cdot 400 \mathrm{~mm}^{3}$ RTL specimen, B - Local measurements of moisture content in the cross section at different depth from the radial surface wetted $(3,8$ and $15 \mathrm{~mm})$ 
the specimen's length). A hammer then excited the axial vibration of the specimens. The sound pressure was registered via a microphone connected to a computerbased data acquisition system. The frequency spectrum was established from the sound pressure using Fast Fourier Transformations (FFT) and the eigen-frequency was determined from the appropriate peak. Based on eigen-frequency $\mathrm{f}[\mathrm{Hz}]$, length $1[\mathrm{~m}]$ and density $\rho[\mathrm{kg} /$ $\left.\mathrm{m}^{3}\right]$, the MOE was calculated as follow:

$$
\mathrm{MOE}_{\mathrm{dyn}}=4 \cdot \rho \cdot \mathrm{f}^{2} \cdot 1^{2}\left[\mathrm{kN} / \mathrm{mm}^{2}\right]
$$

Tab. 1. Properties, sample size LRT in mm, applied standard and number of specimens (n) per treatment

\begin{tabular}{|l|c|c|c|c|}
\hline \multicolumn{1}{|c|}{$\begin{array}{c}\text { Strength } \\
\text { property }\end{array}$} & $\begin{array}{c}\text { Assign- } \\
\text { ment }\end{array}$ & $\begin{array}{c}\text { Specimen } \\
\left(\mathrm{mm}^{3}\right)\end{array}$ & Standard & $\mathrm{n}$ \\
\hline $\begin{array}{l}\text { Parallel } \\
\text { compression }\end{array}$ & $\mathrm{f}_{\mathrm{c}, \mathrm{o}}$ & $30 \times 20 \times 20$ & DIN 52185 & 10 \\
\hline $\begin{array}{l}\text { Parallel } \\
\text { tension }^{\mathrm{a}}\end{array}$ & $\mathrm{f}_{\mathrm{t}, \mathrm{o}}$ & $300 \times 20 \times 15$ & DIN 52188 & 20 \\
\hline $\begin{array}{l}\text { Modulus } \\
\text { of elasticity }^{\mathrm{b}}\end{array}$ & $\mathrm{MOE}_{\mathrm{st}, \mathrm{ppb}}$ & $400 \times 20 \times 20$ & EN 408 & 20 \\
\hline $\begin{array}{l}\text { Modulus } \\
\text { of elasticity }^{\mathrm{c}}\end{array}$ & $\mathrm{MOE}_{\mathrm{st}, 3 \mathrm{pb}}$ & $400 \times 20 \times 20$ & DIN 52 186 & 10 \\
\hline $\begin{array}{l}\text { Modulus } \\
\text { of elasticity }^{\mathrm{d}}\end{array}$ & $\mathrm{MOE}_{\mathrm{dyn}}$ & $400 \times 20 \times 20$ & - & 20 \\
\hline $\begin{array}{l}\text { Modulus of } \\
\text { rupture }\end{array}$ & $\mathrm{MOR}$ & $200 \times 10 \times 10$ & DIN 52 186 & 10 \\
\hline $\begin{array}{l}\text { Moisture } \\
\text { content }^{\mathrm{b}}\end{array}$ & $\mathrm{MC}$ & $400 \times 20 \times 20$ & Protimeter & 5 \\
\hline
\end{tabular}

a Zwick/Roel ZMART.PRO 100kN test machine (Ulm, Germany); ${ }^{\mathrm{b}}$ and ${ }^{\mathrm{c}}$ Zwick/Roel ZMART.PRO $10 \mathrm{kN}$ test machine (Ulm, Germany); ${ }^{\mathrm{d}}$ Grindosonic MK5 (J.W.Lemmens N.V.; Leuven; Belgium); ${ }^{\mathrm{e}}$ creep test according to ENV 1156.

The ACE is determined according to the following equations:

$$
\begin{gathered}
\mathrm{ACE}=\left(\mathrm{dJ}_{\mathrm{u}}-\mathrm{dJ}_{\mathrm{t}}\right) / \mathrm{dJ}_{\mathrm{u}} \cdot 100[\%] \\
\mathrm{dJ}_{\mathrm{i}}=2 \mathrm{~b} \mathrm{~h}^{3} / 3 \mathrm{P} \mathrm{L}_{1} \mathrm{~L}_{3}^{2}\left(\delta_{2}-\delta_{1}\right)\left[\mathrm{MPa}^{-1}\right]
\end{gathered}
$$

where:

$\mathrm{dJ}_{\mathrm{i}} \quad$ - the creep compliance with $\mathrm{i}=\mathrm{u}$ or $\mathrm{i}=\mathrm{t}$,

$\mathrm{dJ}_{\mathrm{t}}$ - the creep compliance for treated timber,

$\mathrm{dJ}_{\mathrm{u}}$ - the creep compliance of untreated timber,

$\mathrm{P} \quad-$ the applied load,

$\delta_{2}-$ the deflection after 42 days,

$\delta_{1} \quad$ - the deflection after $60 \mathrm{~s}$ loading,
$\mathrm{L}_{3} \quad$ - the gauge length for the determination of $\mathrm{MOE}_{\mathrm{st}, 4 \mathrm{pb}}$,

$\mathrm{L}_{1} \quad$ - the span between support and load,

$\mathrm{bh}^{3} / 12$ - the moment of inertia of the cross-section.

The bending deflection was measured from the top surface of the specimen at mid-span with $160 \mathrm{~mm}$ span using lvdt gauges and recorded with PC-based Data logging procedure automatically at $5 \mathrm{~s}$ time intervals (for the first 4 hours) and at each 30 minutes for the next days. The same procedure was repeated every week cycle.

The relative creep $\left(\phi_{t}\right)$ was calculated as the deflection at a specific time divided by the deflection after 60 seconds $\left(\delta_{0}\right)$. The creep factor $\left(\mathrm{k}_{\mathrm{c}}\right)$ was calculated as the increase in deflection with time $\left(\delta_{c}\right)$ divided by the initial elastic deflection, after $60 \mathrm{~s}$. Where $\delta_{\mathrm{t}}$ is the deflection at time $\mathrm{t}$ and $\phi_{\mathrm{t}}$ is the relative creep at time $\mathrm{t}$ :

$$
\mathrm{k}_{\mathrm{c}}=\left(\delta_{\mathrm{t}}-\delta_{0}\right) / \delta_{0}=\delta_{\mathrm{c}} / \delta_{0}-1=\phi_{\mathrm{t}}-1
$$

For comparative analysis of creep results (relative creep with time, $\Phi_{t}$ ) the power function model (PFM) with three coefficients was used:

$$
\Phi_{\mathrm{t}}=\beta_{0}+\beta_{1} \cdot \mathrm{t}^{\beta 2}
$$

where $\beta_{0}$ represents the instantaneous elastic deformation and can be calculate from the MOE and the size of the specimens for any given load, according to the material behaviour:

$$
\Delta_{4} \cong 3 \mathrm{P} \mathrm{L}_{3}^{2} \mathrm{~L}_{1} /\left(4 \mathrm{~b} \mathrm{~h}^{3} \mathrm{E}\right)
$$

where:

$\mathrm{P}$ - the load at each side,

$\mathrm{L}_{1}$ - the span between load-shoes and support,

E - modulus of elasticity,

$\mathrm{L}_{3}$ - the span where the curvature where measured.

The second term $\beta_{1} \cdot t^{\beta 2}$ of the PFM is the creep deflection. The parameters $\beta_{1}$ describe the slope of the relative creep curve and $\beta_{2}$ is the power factor that translate the influence of time. This second term grows with time approaching an asymptotic limit.

\section{Results AND DISCUSSION}

All studied properties of untreated and modified wood were characterized by mean value (x), median (horizontal line in the box plot) and standard deviation (box). 
The whisker plots displayed the 5 and $95 \%$ percentile range. For comparative purposes, a t-test analysis was carried out to verify whether a change was significant. The level for significance was set at $\mathrm{p}<0.05$.

For fitting creep curves and forecasting data, the ORIGIN statistical software was used. For unconstrained models, the default algorithm used by ORIGIN is the Gauss-Newton method of finding the minimum of function that is a sum of squares of non-linear functions.

\section{Moisture content distributions}

To check the MC distributions in the cross section, a preliminary experiment was done where allowed clarifying some doubts:

- The first one, it was an attempt to establish the length of the cycle for the creep test duration, in a way to reach the wood stabilization after the wet and dry cycle.

- The second one, it was how far the moistening process is suitable to produce a MC changing. Special care had taken in the study of modified specimens.

- The last ones were checked the MC above and below of the neutral axis (n.a.). Which level of MC was reached with this asymmetric moistening procedure above the n.a. whilst below n.a., no changes were expected.

Figure 2 shows the means values of MC distribution on the specimens cross section during their moistening at different depth, see also fig. 1B.

Below the n.a. the MC was not affected by the moistening. However above n.a. both materials stud- ies (control pinewood, in the fig. 2A and DMDHEU treated wood, in the fig. $2 \mathrm{~B}$ ) had reached similar $\mathrm{MC}$ to the EMC found in the wetted stabilized conditions, RH of $87 \%$. Only one part of the cross section (up to the n.a.) changed the MC in a way to produce the mechanosorptive effect.

Resin based treatment took up to five days to reach and stabilize the preliminary EMC, before moistening. On the other hand, untreated pine took up to three days to stabilize, despite higher MC was reach. One week for the length of cycle in the MSE in bending creep was taken.

Protimeter MMS moisture-meter was able to access the MC in the pine wood and other species well identified. Therefore, it is not appropriated to access directly the MC in the modified wood with DMDHEU resin, despite similar density was used. The found MC should be considered a rough approach.

In the literature, Pfeffer (2011) with untreated Scots pine and resin based treatment (DMDHEU) had shown significant correlations between the MC measured by gravimetric and by electrolyte method.

\section{Mechanical properties}

Figure 3 shows different enhancement on the strength properties in the modified pinewood. Compression strength parallel to the grain increased significantly for resin based treatments, with large extend in DMDHEU than MMF resin.

In the Lumen fill treatments, TEOS had no effect and wax had shown a slight increased, up to $15 \%$, fig. 3A.

\section{B}

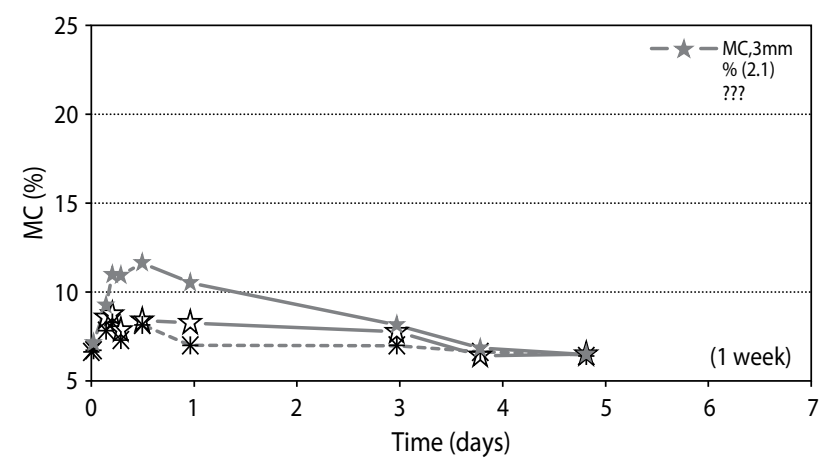

Fig. 2. Profile of the moistening the top radial surface, A - untreated pinewood and B - DMDHEU (D1, 15\% WPG) ( $\star 3 \mathrm{~mm}$; $\star 8 \mathrm{~mm}$ and $*$ at $15 \mathrm{~mm}$, see also fig. $1 \mathrm{~B}$ ) 


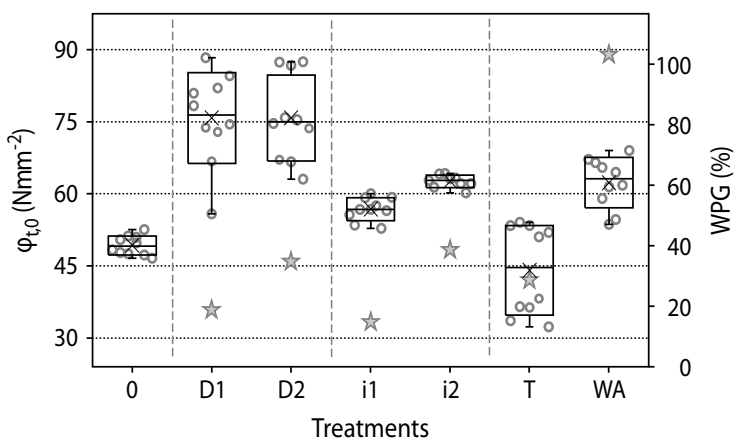

B

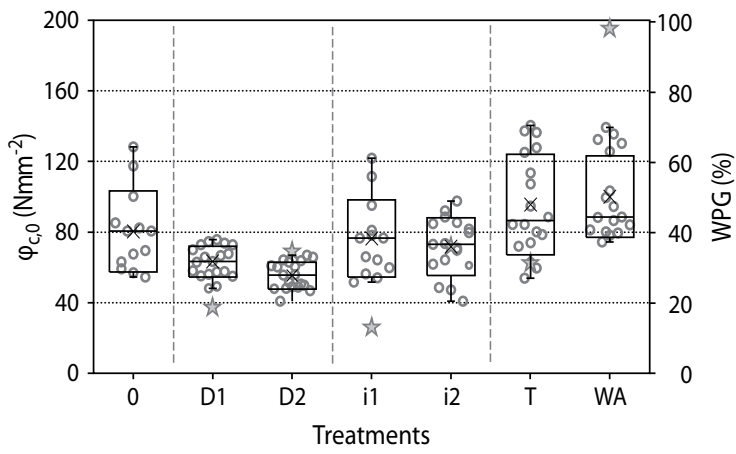

Fig. 3. A - Compression strength; B - tension strength and WPG $(\star)$. For abbreviation see material item

Tension strength parallel to the grain acted in the same way for lumen fill treatments, but in the other way around resins based treatments. High concentration of DMDHEU resin (D3, 35\% WPG) was reduced up to $25 \%$. In the remaining resin type and concentrations as well in the lumen fill treatment (TEOS and wax) did not shown a significant effect despite the WPG observed, fig. 3B.

The hardness increase and the embrittlement effect of the cell wall reaction are the main contributor to this behaviour (Rowell 1996; Mai et al. 2007; Xie et al. 2007).

For both moistening setups done at $12 \mathrm{~N} / \mathrm{mm}^{2}$ of stress level no failures were occurred.

\section{Wetted compression zone}

Figure 4 shows some of the compliance curve of relative creep in four points bending $(4 \mathrm{pb})$ according to EN 408 and ENV 1156 when the moistening process was done in the compression zone.

In all specimens, cells wall reaction treatments (DMDHEU and MMF resins), TEOS and untreated specimens, an increasing of moisture content means a creep deflection variation. Therefore, drying process tends to have a different displacement recover between cell wall reaction and lumen fill treatments. At the $2^{\text {nd }}$ days of the cycle, untreated wood and TEOS treatment had shown stabilized creep deflection. In the resin based treatments, the stabilization deflection took place at the $4^{\text {th }}$ up to $5^{\text {th }}$ day of the cycle.

To represent the mean deflection and achieved the mean relative creep, the compliance creep curves obtained from creep tests were fitted by power function model - PFM. The PFM is designed to fit primary creep and does not include a term that would indicate the possibility of accelerated creep to failure.

The slope of the fitting curve translates the creep limit which has a particular interest to analyze and compare the creep behaviour (Hunt and Shelton 1988). Mohager and Toratti (1993) had shown no creep limit with different size specimens of untreated Scots pine under MSE over long-term (8 years). That means, with successive wetted and dry cycles, the creep deformation is unstable or increases indefinitely.

Between modified wood with resins (DMDHEU and MMF) and untreated wood, the difference of the slope creep curves was clearly. One possible explanation is that moisture in untreated wood acts as a plasticizer (Holzer et al. 1989), i.e. the deflection increases with increasing moisture content as a result of MC and MOE variation. Modified wood with resin based had shown the same trends with moistening in the stiffness stabilization efficiency (SSE) and (ASE) anti-swelling efficiency (Norimoto et al. 1992; Epmeier et al. 2005).

In the beginning of each cycle of untreated wood creep, the wetting causes swelling and concomitantly a larger moment of inertia responsible for the negative peak of deflection. The first adsorption causes an increase in deformation in different extend from the next ones. The following adsorption cycles had caused an increase deflection in the less extend, see fig. 4A. Modified wood had shown the same instability with less extend between the first and next cycles. The best performances of resins based treatments in ASE and SSE help to explain its lesser extent (fig. 4B and C).

Figure 5 shows the relative creep for wax specimens tested under similar moistening process in the compression zone than control and resin based treatments. The wax treatment had shown a hydrophobic behaviour. For that reason no experiment with wax were done in the tension zone moistening. The hydrophobic effect of the wax 
A

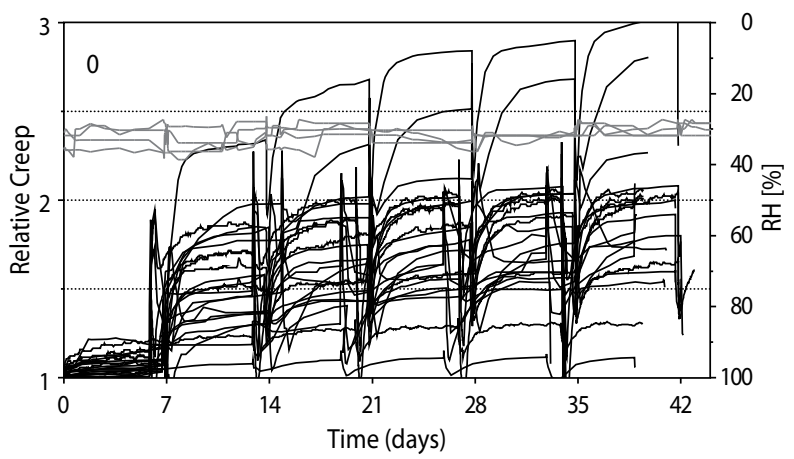

B

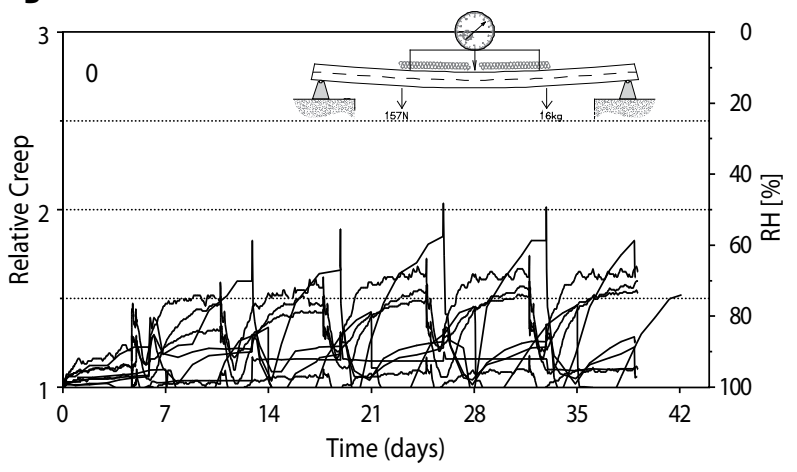

C

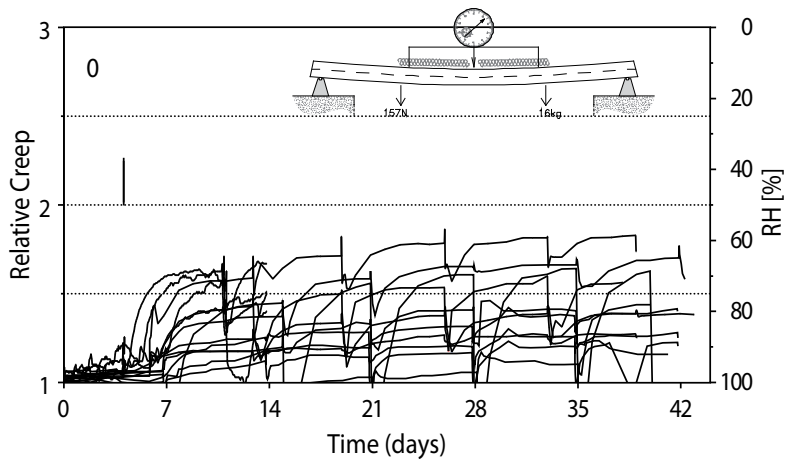

Fig. 4. Compliance curves of relative creep and $\mathrm{RH}$ environment conditions for pinewood $\mathrm{A}-0 \mathrm{ctrl}$, $\mathrm{B}$ - DMDHEU (1.3M, 18\% WPG) and C - MMF (16\% WPG)

and the slower water penetration presented by Scholz et al. (2009) with similar wax, can be explained the creep behaviour of wax treatment. The evaporation took place first then the capillarity water uptake/absorption into the wood material. The sealer effect of wax did not let shown the mechano-sorptive effect. Actually, the MSE doesn't judge completely eradicated in the wax treated wood. However, surround environment change will have a less effect and move forward with phase. This means, when the wood start to wet the surround environment conditions start to dry. It is credible for practical applications that the wax in lumen of the cell wall avoids the water circulations through the wood material.

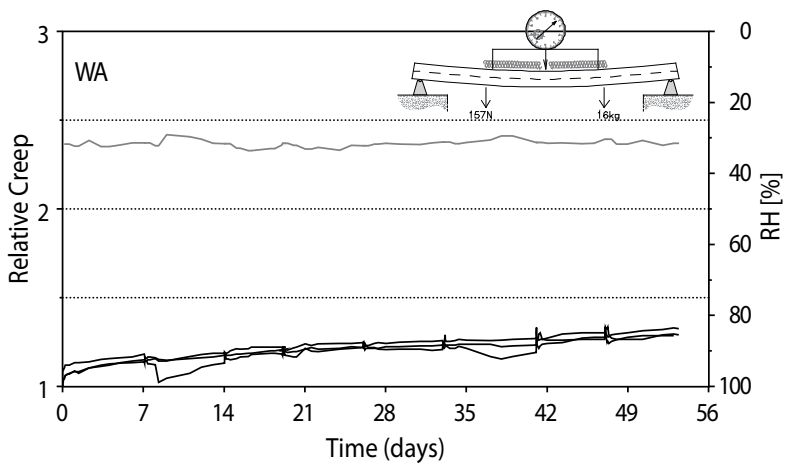

Fig. 5. Compliance curve of relative creep and RH environment conditions for pinewood treated with wax (95\% WPG)

\section{Wetted tension zone}

Figure 6 shows the compliance curve of relative creep with moistening process in the tension zone. As in the compression zone wetting process, untreated wood had shown no creep limits. In the other hand, modified wood had shown less amplitude than untreated wood behaviour and a constant balance. At the end of the experiments (42 days/1000 hours), the slope or the creep limits can be translate by $\mathrm{k}_{\mathrm{c}}$ factor, see fig. $7 \mathrm{~B}$.

Figure 7 shows the creep factor $\left(\mathrm{k}_{\mathrm{c}}\right)$ over 42 days/ 1000 hours and 5 wet/dry cycles. For both process of moistening, $\mathrm{k}_{\mathrm{c}}$ were obtained from the mean relative creep curves fitted with PFM following the eqt. 5. Resin based treatments had shown similar behaviour and less creep than untreated wood. In the lumen fill treatments, TEOS had shown no effect and wax treatment had shown a particular effect.

In the modified wood with resin based treatments, fitting curves of relative creep had shown lower and less scattered creep factors $\left(\mathrm{k}_{\mathrm{c}}\right)$ at 42 days forecasting.

Whilst in the lumen fill treatment (TEOS) the creep factor $\left(\mathrm{k}_{\mathrm{c}}\right)$ did not shown any difference to untreated pinewood.

Under uniform changing of RH environment (30 and 90\%), Mohager and Toratti (1993) with small specimens $10 \times 10 \times 330 \mathrm{~mm}$ RTL of Scots pine had found a creep factor of 1.05 . In the same conditions but with 
specimens with full scale dimensions $1: 1$, Toratti (1993) was shown an increase of creep factor app. 0.80 . Epmeier (2006) conducted a study with a large and well-documented provenance specimens with full scale $1: 1$ and showed a range creep factor between 1 to 1.35 . Bengtsson (2001) with untreated wood from different positions of the stem (heart and sapwood) and type of tree (fast and slow growth) showed a range of creep factor between 0.9 up to 1.57 .
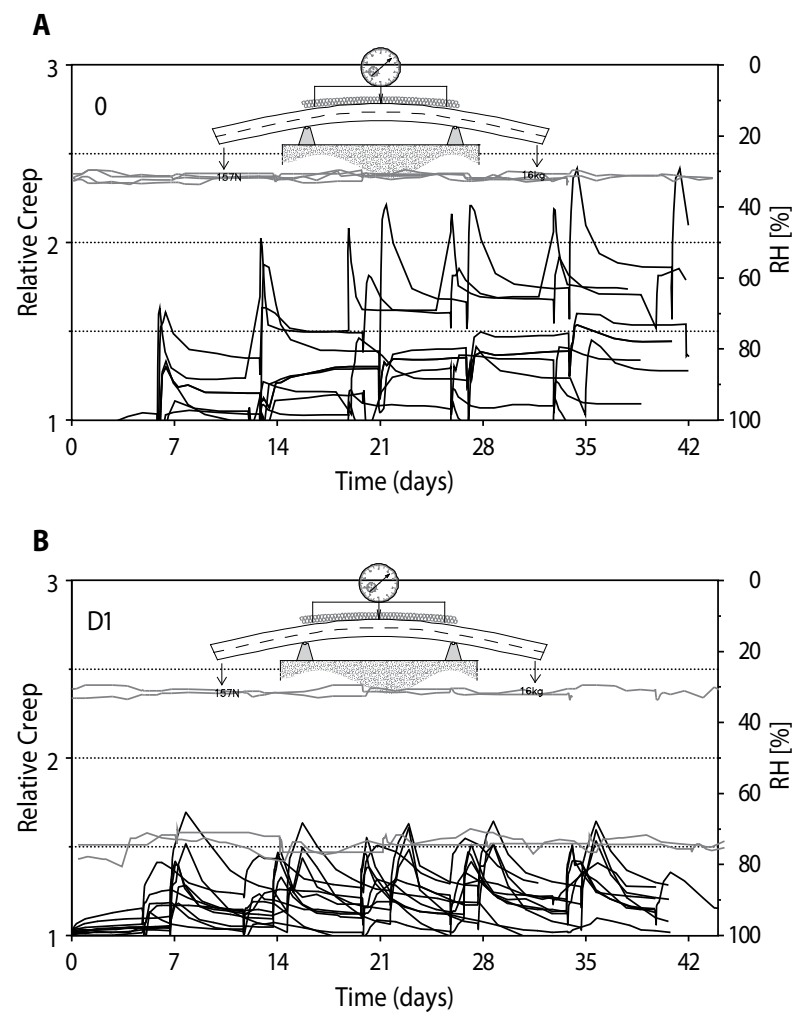

Fig. 6. Compliance curve of relative creep for A - untreated pinewood, $0 \mathrm{ctrl}$ and $\mathrm{B}$ - DMDHEU (1.3M, 18\% WPG) and $\mathrm{RH}$ conditions

In this study of the MSE in the tension moistening zone with untreated pinewood had shown similar results than Roszyk (2005). He worked with Scot pine pure sapwood and similar setup, a mean value of creep factor up to 0.80 was shown.

Our results of the creep factor for the MSE with short dimension specimens $1: 10$ became in line with literature results for other pines in full $1: 1$ or small $1: 10$ scale specimens.

The MSE in the unidirectional tension creep is less than in compression with ratio $1: 2$ (Bengtsson 2000).
Comparatively, the mechano-sorptive in bending with $4 \mathrm{pb}$ of untreated pinewood had shown lower creep factor for tension than compression zone moistening (15\%). Similar bending setup for tension and compression together, Roszyk (2005) had shown means creep factor $35 \%$ less in tension moistening zone. The difference between both results can be explained mainly for two reasons: The ratio V/A exposed to the moistening and the stress level $50 \%$ higher, $18 \mathrm{~N} / \mathrm{mm}^{2}$. Schniewind (1967 and 1968) suggested that a lower value of the ratio $\mathrm{V} / \mathrm{A}$, the higher pronounced of MSE is.

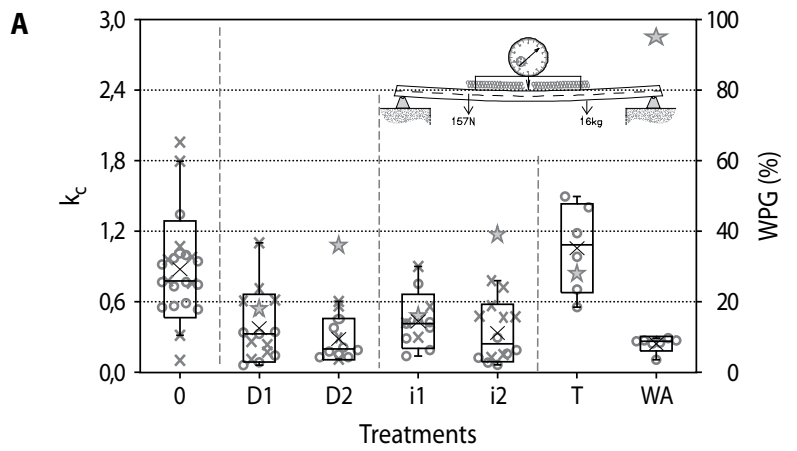

B

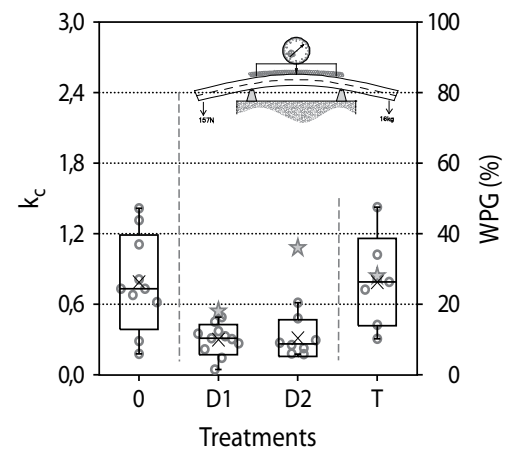

Fig. 7. Creep factor $\left(k_{c}\right)$ over 42 days with wetting at, $\mathrm{A}-$ compression zone and $\mathrm{B}-$ tension zone with $4 \mathrm{pb}$ and WPG $(\star)$. For abbreviation see the material item

Table 2 shows the creep factor in the MSE for both moistening setups in compression and tension zone.

Modified wood with DMDHEU resin did not shown significant difference between both setups. Lumen fill treatment (TEOS) had shown a creep factor $\left(\mathrm{k}_{\mathrm{c}}\right) 20 \%$ lower in tension moistening.

Over 42 days with 5 wet and dry cycles, modified wood with resin based (DMDHEU and MMF) had shown a significant reduction on the creep factor $\left(\mathrm{k}_{\mathrm{c}}\right)$ greater than $50 \%$, see also figure $7 \mathrm{~A}$. MMF with 
lower concentration (i1) had shown less reduction than DMDHEU resin.

Tab. 2. Mean of creep factor $\left(\mathrm{k}_{\mathrm{c}}\right)$ and difference between modified wood and untreated with [non significant values]

\begin{tabular}{|l|c|c|c|c|c|c|c|}
\hline $\begin{array}{c}\text { Wet / } \\
\text { Treatment }\end{array}$ & 0-ctrl & D1 & D2 & i1 & i2 & T & WA \\
\hline $\mathrm{k}_{\mathrm{c}}\left(\mathrm{f}_{\mathrm{c}, \mathrm{o}}\right)^{\mathrm{a}}$ & 0,89 & 0,33 & 0,28 & 0,41 & 0,29 & 1,05 & 0,24 \\
\hline Difference [\%] & - & -63 & -69 & -54 & -68 & +18 & -73 \\
\hline $\mathrm{p}$-value & - & 0,00 & 0,00 & 0,00 & 0,00 & {$[0,32]$} & 0,00 \\
\hline $\mathrm{k}_{\mathrm{c}}\left(\mathrm{f}_{\mathrm{t}, \mathrm{o}}\right)^{\mathrm{b}}$ & 0,79 & 0,30 & 0,31 & - & - & 0,79 & - \\
\hline Difference [\%] & - & -62 & -60 & - & - & $+0,08$ & - \\
\hline p-value & - & 0,01 & 0,01 & - & - & {$[0,77]$} & - \\
\hline
\end{tabular}

${ }^{\mathrm{a}}$ Creep factor with moistening in the compression zone;

${ }^{\mathrm{b}}$ moistening in the tension zone of bending creep test over 42 days/1000 hours according to ENV 1156.

Both levels of DMDHEU modifications (D1 and D2 with 18 and 36\% WPG used in this study) had shown a slight decrease in the creep factor, up to $2 \%$. This result has an important meaning in the industrial scale of chemical modification where the dimension specimen plays an important role. Wood with large cross section has the propensity to establish internal chemicals gradient. Homan and Bongers (2004) had shown a gradient of app. $50 \%$ with uneven chemical distribution in the cross section (great than $50 \mathrm{~mm}$ ). Epmeier and Kliger (2005) with full scale specimens modified with both concentrations of MMF treatment (with 7.5 and 15\%) had shown no significant difference in the MSE of bending creep. Similar results, with no significant difference, were shown in this study with MMF (with $15 \%$ and $30 \%$ concentration). A minimum level and sufficient cell all modification are required to achieve the enhancement of the MSE on the bending creep.

Furfurylated wood is a similar treatment to the DMDHEU resin with high concentration. Epmeier et al. (2007) with furfurylated specimens in full-scale $1: 1$ under symmetric moisture change found a creep factor up to $75 \%$.

DMDHEU resin had shown a mean value up to $30 \%$. The ratio V/A exposed to the moistening and setup used should be the main reasons to justify both results.

In this study, MMF with medium concentration had shown similar creep factor (up to $41 \%$, mean value), as Epmeier and Kliger (2005) and Norimoto et al. (1992) with similar concentration. Despite, differences in the setup and V/A ratio of specimens, respectively with full scale $1: 1\left(\mathrm{k}_{\mathrm{c}} 47 \%\right.$ of creep factor) and the latter authors with small scale $1: 15$ (mean value of creep factor, up to $40 \%)$.

Under different set up conditions but with acetylated wood, the latter's authors found similar creep factor, up to $30 \%$.

\section{Correlation analyses}

Several authors correlate the stiffness (short-term properties) or the wood quality (MOE/density) to the long-term performance in the creep test of untreated wood (Hoyle et al. 1985; Bengtsson 2001). Epmeier et al. (2007) corroborated the later results for Scots pine but had found minor correlation in the modified wood, i.e. acetylation, MMF, heat treatment in oil bath and furfurylation.

The density is an important wood feature and often regarded as being closely related to deformation (or resistance). Table 3 shows different correlation between Density, stiffness and deformations found in the creep tests. As far as untreated wood were concerned moderate up to significant correlation were found.

In the modified specimens, despite few specimens tested (seven) in the lumen fill treatment (TEOS), the tendency of correlation remained between density and other properties.

In the cell wall treatments (DMDHEU and MMF resins) the correlations in the most cases were lower. Occasionally significant correlations were found, but not confirmed in other concentrations or similar treatments.

As a summarizing, the prediction of performance criteria based exclusively on density should not be formulated for modified wood. Although, in the stiffness accessed with vibration technique $\left(\mathrm{MOE}_{\mathrm{dyn}}\right)$ for untreated and treated wood with high concentration of resin (DMDHEU and MMF) significant correlations were found.

Correlation between creep deflection and relative creep is moderate for the untreated control and DMDHEU (D1, with medium concentration) and significant for DMDHEU (D2, with high concentration), MMF and TEOS.

Despite the particular hydrophobic behaviour of the wax treatment no significant correlation were found. 
Tab. 3. Coefficients of correlation for modified wood specimens and untreated pine at each moistening process, [nonsignificant values] in brackets. For abbreviations see the material item

\begin{tabular}{|c|c|c|c|c|c|c|c|c|c|}
\hline \multicolumn{3}{|c|}{ Treatments } & 0 & D1 & $\mathrm{D} 2$ & i1 & i2 & $\mathrm{T}$ & WA \\
\hline \multicolumn{10}{|c|}{$f_{c, o}$ wetted Compression side } \\
\hline Density & vs. & $\mathrm{MOE}_{\mathrm{dyn}}$ & +0.69 & {$[+0.10]$} & +0.61 & {$[+0.07]$} & +0.60 & +0.56 & {$[+0.37]$} \\
\hline Density & vs. & $\mathrm{MOE}_{\mathrm{st}, 4 \mathrm{pb}}$ & +0.77 & {$[+0.30]$} & {$[+0.50]$} & {$[0.32]$} & {$[+0.47]$} & {$[+0.11]$} & {$[+0.28]$} \\
\hline Density & vs. & $\mathrm{MOE}_{\mathrm{st}, 3 \mathrm{pb}}$ & +0.69 & {$[+0.14]$} & {$[+0.4]$} & {$[+0.54]$} & +0.56 & +0.91 & {$[+0.33]$} \\
\hline Density & vs. & relative creep & -0.86 & {$[-0.05]$} & {$[-0.54]$} & {$[-0.25]$} & {$[-0.18]$} & -0.78 & {$[-0.02]$} \\
\hline Density & vs. & creep deflection & -0.70 & {$[-0.01]$} & {$[+0.15]$} & {$[-0.42]$} & {$[-0.26]$} & -0.68 & {$[-0.44]$} \\
\hline Creep deflection & vs. & relative creep & {$[+0.43]$} & {$[+0.35]$} & +0.74 & +0.64 & +0.62 & +0.85 & {$[+0.01]$} \\
\hline Creep deflection & vs. & $\mathrm{MOE}_{\mathrm{st}, 4 \mathrm{pb}} / \mathrm{DEN}$ & {$[-0.33]$} & {$[-0.45]$} & {$[-0.36]$} & {$[-0.48]$} & {$[-0.18]$} & {$[-0.26]$} & -0.80 \\
\hline Creep deflection & vs. & $\mathrm{MOE}_{\mathrm{st}, 4 \mathrm{pb}}{ }^{*}$ & -0.67 & {$[-0.35]$} & {$[-0.54]$} & -0.80 & {$[-0.35]$} & {$[-0.39]$} & {$[-0.37]$} \\
\hline \multicolumn{10}{|c|}{$\mathrm{f}_{\mathrm{t}, \mathrm{o}}$ wetted Tensile side } \\
\hline Density & vs. & $\mathrm{MOE}_{\mathrm{dyn}}$ & +0.67 & {$[+0.24]$} & {$[+0.32]$} & - & - & +0.84 & - \\
\hline Density & vs. & $\mathrm{MOE}_{\mathrm{st}, 4 \mathrm{pb}}$ & +0.78 & {$[+0.09]$} & {$[+0.14]$} & - & - & +0.60 & - \\
\hline Density & vs. & $\mathrm{MOE}_{\mathrm{st}, 3 \mathrm{pb}}$ & +0.73 & {$[+0.16]$} & {$[+0.11]$} & - & - & +0.68 & - \\
\hline Density & vs. & relative creep & -0.72 & {$[-0.01]$} & {$[-0.04]$} & - & - & -0.64 & - \\
\hline Density & vs. & creep deflection & -0.63 & {$[-0.11]$} & {$[+0.04]$} & - & - & {$[-0.42]$} & - \\
\hline Creep deflection & vs. & relative creep & {$[+0.54]$} & +0.64 & +0.81 & - & - & +0.56 & - \\
\hline Creep deflection & vs. & $\mathrm{MOE}_{\mathrm{st}, 4 \mathrm{pb}} / \mathrm{DEN}$ & -0.84 & {$[-0.08]$} & {$[-0.04]$} & - & - & {$[-0.49]$} & - \\
\hline Creep deflection & vs. & $\mathrm{MOE}_{\mathrm{st}, 4 \mathrm{pb}}$ & -0.62 & {$[-0.48]$} & {$[-0.44]$} & - & - & -0.93 & - \\
\hline
\end{tabular}

* These correlation are shown in fig. 11.

The surface wax isolated the wood material from the exterior environment. However, in the lumen fill treatment with wax, the EMC and ASE did not changed.

High correlation between creep deflection vs. $\mathrm{MOE}_{\mathrm{st}, 4 \mathrm{pb}}$ could be expected, as the $\mathrm{MOE}_{\mathrm{st}, 4 \mathrm{pb}}$ was calculated from the (creep) deflection after $60 \mathrm{~s}$. In actual fact, two deflections were compared: the deflection after $60 \mathrm{~s}$ (under a short-term load) and the deflection after 6 weeks with five wet and dry cycles under a sustained load.

The short-term deformation $\left(\mathrm{MOE}_{\mathrm{st}, 4 \mathrm{pb}}\right.$ or $\left.\mathrm{MOE}_{\mathrm{dyn}}\right)$ is moderate to significantly correlated to the long-term creep deflection. This indicates that measuring the stiffness of a structural member, it should be possible to predict roughly its long-term performance under load.

In both moistening process, the results of this study confirm the suggestions from the literature, where the main correlation fitted (moderate up to significantly) for untreated pinewood (Epmeier 2006; Bengtsson 2001).

The lumen fill treatment (TEOS) had no effect on the MSE, however had shown the best correlation (moderate up to significant) with different variables.
The correlations shown by MMF resin (i2, high concentration) are not confirmed by DMDHEU treatment.

Creep deflection and stiffness had shown the best correlations. Moderate up to significant for control and TEOS treatments, except for resin based treatments with high concentration.

For cell wall treatments (DMDHEU and MMF resins) any clear pattern can be drawn for relative creep.

Epmeier (2006) with treated full scale specimens $1: 1$ with cell wall treatments (acetylation, MMF resin and thermowood in oil bath) under MSE had shown significant correlation for $\mathrm{MOE}_{\text {dyn }}$, Density and creep deflection. However they were not confirmed with relative creep vs. $\mathrm{MOE}_{\text {stat }}$ and in furfurylated wood specimens. In the same works, controls and MMF treatments had shown the best correlations.

In figure 8, scatter plots for the correlations between creep deflection (on the x-axis) and $\mathrm{MOE}_{\mathrm{st}, 4 \mathrm{pb}}$ (on the $y$-axis) are shown. The corresponding coefficients of correlation can be found in table 3 (Creep deflection vs. $\left.\mathrm{MOE}_{\mathrm{st}, 4 \mathrm{pb}}\right)$. 

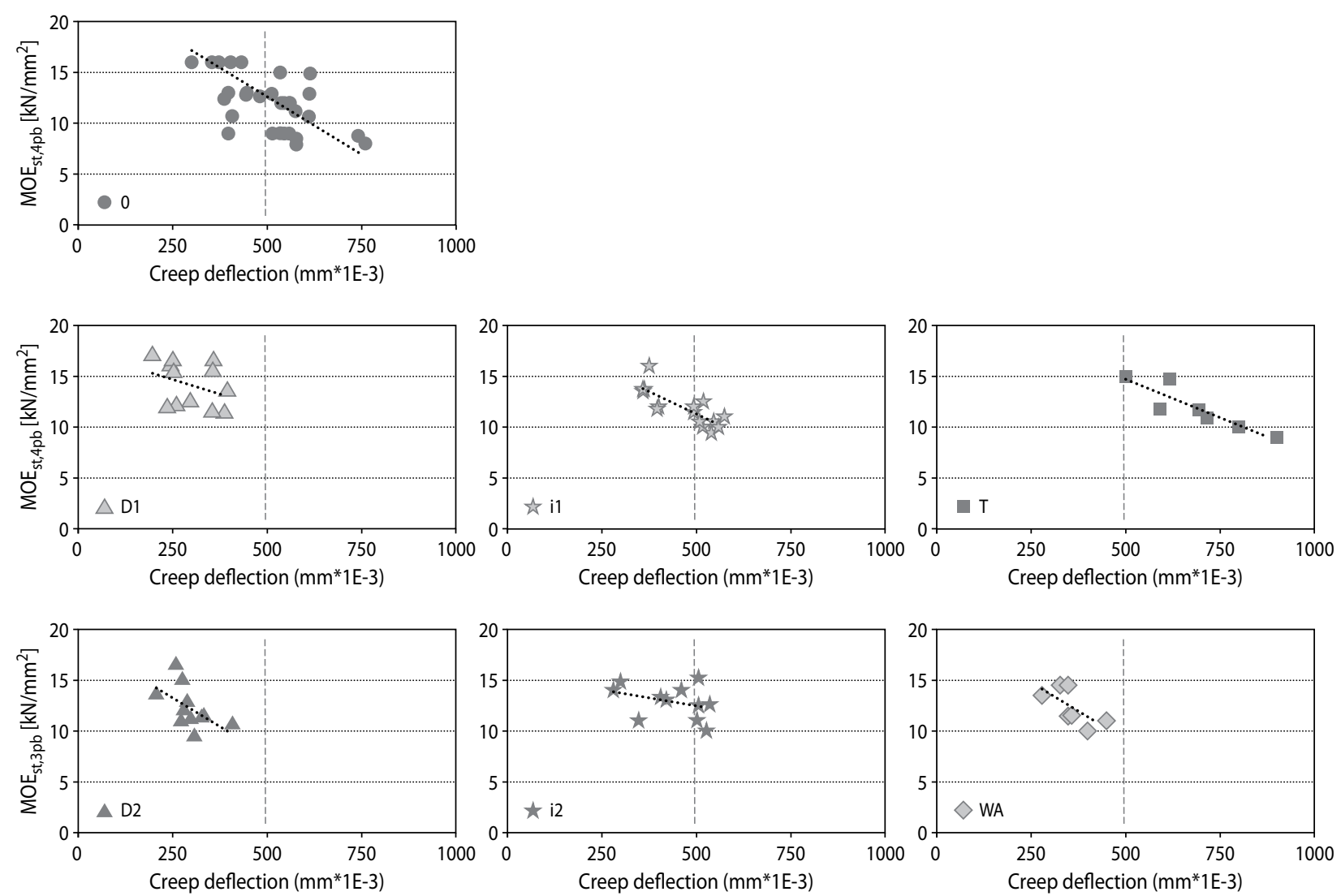

Fig. 8. Correlation scatter plots between creep deflection $[\mathrm{mm}]$ and $\mathrm{MOE}_{\mathrm{st}, 4 \mathrm{pb}}\left[\mathrm{kN} / \mathrm{mm}^{2}\right.$ or GPa] under $\mathrm{SL}$ of $12 \mathrm{Nmm}^{-2}$ over a period of 42 days $/ 1000 \mathrm{~h}$. For abbreviations see the material item

In the lumen fill treatments (TEOS and wax) significant values were found and untreated pinewood had shown moderate correlation.

In the cell wall treatments (DMDHEU and MMF resin, medium concentration) moderate correlation were found (not significant). It seems that for high concentration in the resin based treatments, the correlation disappeared.

The control and lumen fill treatments (TEOS and wax) were correlated better than the cell wall modified specimens (DMDHEU and MMF resins).

\section{Anti-creep efficiency (ACE)}

The effect of chemical treatments on the MSE of wood can be characterized by the anti-creep efficiency (ACE) factor, which quantifies the ability of the treatment to reduce the MSE. The higher value for ACE, larger the reduction in creep is (Norimoto et al. 1992).
Figure 9 shows the ACE for all modification methods in both moistening process. The lumen fill treatment TEOS had shown lower ACE, near null (in the compression moistening a negative result was founded, whilst for tension moistening process a positive up to $+9 \%$ was found). No effect in bending creep deflection by TEOS treatment is consistent with ASE and SSE, although both latter properties expressed different behaviour at itself.

Wax treatment was shown a particular behaviour and the high ACE presented was a surprise and in the other way around than ASE and SSE. The wax acts as a hurdle to the moisture change.

The wax effect in the lumen fill treatment clearly reduced the capillary water uptake in a ratio of $5: 1$ (Scholz et al. 2009). Similar results was found by RantaMaunus and Kortesmaa (2000) with full scale beams $1: 1$ under service conditions with surface coating with 
alkyd paint. Santos (2009) suggested that glulam beams $1: 1$ with protected surface creep less.

The most effective modification were cell wall treatments, where DMDHEU performed best than MMF resin and different concentrations of resins did not shown significant different ACE.

A

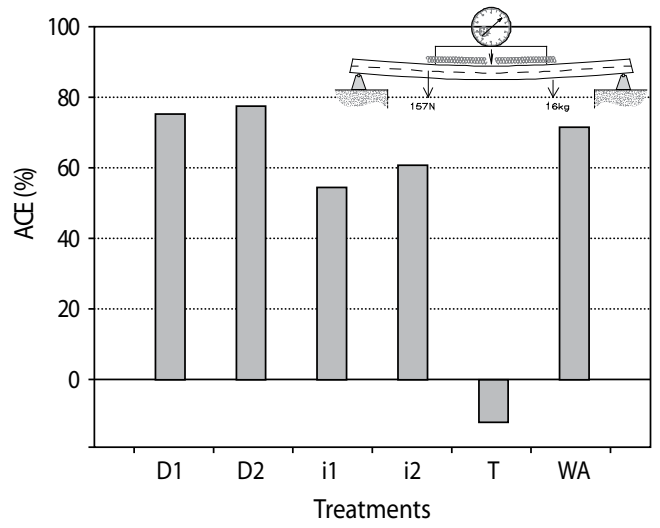

B

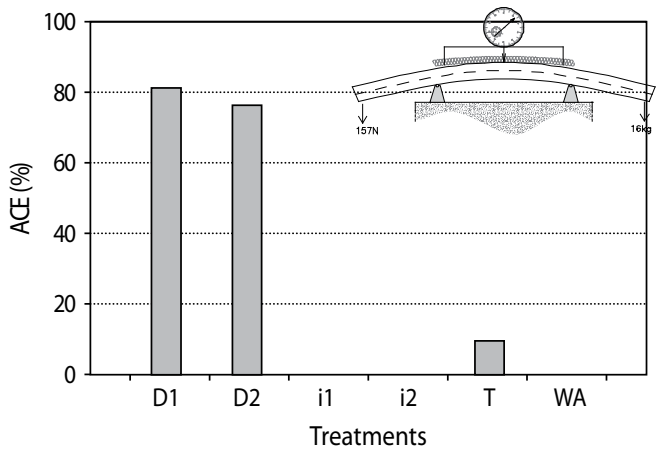

Fig. 9. Anti-creep efficiency (ACE) for compression $-\mathrm{A}$ and $\mathrm{B}-$ tension zone moistening. For abbreviations see material item

Few references in bending creep of modified wood are found. A summary is present in the table 4.

Although different setup to access the MSE has been used, ACE in acetylation and heat treatment wood specimens presented by different authors were comparable (Norimoto et al. 1992; Epmeier et al. 2005). The furfurylation treatment is roughly similar to the cell wall treatment DMDHEU (D2, with high concentration, $2.3 \mathrm{M}$ ). In this study, cell wall treatments (DMDHEU and MMF resins) had shown comparable ACE as furfurylated and MMF resins in Epmeier et al. (2007).

Relating $\mathrm{ACE}$ to changes in $\mathrm{MC}$ or $\triangle \mathrm{MC}$, in order to predict the effect of modification on the reduction in creep behaviour does not seem feasible (Epmeier et al. 2007). The resin based treatments (DMDHEU and MMF) had shown different extend reduction in EMC, with $40 \%$ and $20 \%$ in wet or dry conditions for both types of resin, respectively. Any correlation between ACE presented in this study and the EMC or DEMC were found, despite the DMDHEU had shown best performance than MMF resin in ACE, EMC and DEMC. In general for cell wall treatments, the extent of $\mathrm{ACE}$ is in the same trends than the extent of change in ASE. The higher the ASE, higher the ACE is. However, modifications that lead to high ASE and to negative ACE at the same time may exist. Etherification with propylene oxide and polyethylene glycol impregnation are some examples presented by Norimoto et al. (1992).

Tab. 4. Weight percent gain (WPG), anti-swelling efficiency (ASE) and anti-creep efficiency (ACE) of different modification methods

\begin{tabular}{|l|c|c|c|l|}
\hline \multicolumn{1}{|c|}{ Treatment } & $\begin{array}{c}\text { WPG } \\
{[\%]}\end{array}$ & $\begin{array}{c}\text { ASE } \\
{[\%]}\end{array}$ & $\begin{array}{c}\text { ACE } \\
{[\%]}\end{array}$ & \multicolumn{1}{|c|}{ Authors } \\
\hline Acetylation & 23 & 66 & 48 & $\begin{array}{l}\text { Norimoto et } \\
\text { al. } 1992\end{array}$ \\
\hline Acetylation & 13 & 70 & 53 & $\begin{array}{l}\text { Epmeier et al. } \\
2004,2005\end{array}$ \\
\hline $\begin{array}{l}\text { HT }^{*} \\
\left(180^{\circ} \mathrm{C} / 3-10 \text { h) }\right.\end{array}$ & $-2.4 /-3.5$ & $11 / 17$ & $16 / 22$ & $\begin{array}{l}\text { Norimoto et } \\
\text { al. } 1992\end{array}$ \\
\hline HT $^{* *}\left(160 / 190^{\circ} \mathrm{C}\right)$ & - & - & $22 / 25$ & $\begin{array}{l}\text { Epmeier et al. } \\
2007\end{array}$ \\
\hline MMF 7.5\% & 10 & - & 59 & $\begin{array}{l}\text { Epmeier et al. } \\
2005\end{array}$ \\
\hline Phenol Resin & 13 & 30 & 47 & $\begin{array}{l}\text { Norimoto et } \\
\text { al. } 1992\end{array}$ \\
\hline MMF 15\% & 16 & - & 64 & $\begin{array}{l}\text { Epmeier et al. } \\
2006\end{array}$ \\
\hline i1 MMF 15\%
\end{tabular}

* Heat treatment with the same temperature and different times, 3 and 10 hours; ${ }^{* *}$ Heat treatment in vegetable oil bath; ${ }^{* * *}$ ACE values found with moistening process in compression and tension zone in bending 


\section{Conclusions}

The results of this study with Portuguese untreated and modified wood in small scale $(1: 10)$ seem to fit with the results found in literature, with less scale $1: 15$ by Norimoto et al. (1992) and higher scale $1: 1$ by Epmeier et al. (2005) and Epmeier et al. (2007).

It can also conclude that the aims of the present study were fulfilled. Knowledge about the MSE in bending creep along the grain was acquired for modified wood with DMDHEU, MMF, TEOS and amid wax and untreated wood.

Relative creep after 42 days/1000 hours appears to be clear identified with this setup.

Untreated wood and lumen fill treatment with TEOS presented no creep limit. On the other hand, MSE of the modified wood with resins had shown a creep limits and generated stable displacement amplitude.

Cell wall modified wood (DMDHEU and MMF resin) decreased significantly the creep deflection, relative creep and enhanced the homogeneity of the creep results.

Lumen fill treatment with TEOS had no effect in the creep deflection.

From the correlations studied here, $\mathrm{MOE}_{\mathrm{dyn}}$ has the best chance of becoming a functional indicator of relative creep. However, to prove this, a much broader statistical base is needed to enhance the significance of this correlation.

The density for modified wood cannot be used to predict any performance in creep in the same way as they can for untreated wood.

The effect of wood modifications on mechanosorptive creep has been characterized by the anti-creep efficiency (ACE) factor, analogous to anti-swelling efficiency (ASE). However, only in the cell wall treatments (DMDHEU and MMF resin) were found a good correlation between ASE and ACE.

The change of the equilibrium moisture content imparted by the modification, mainly in the cell wall treatments, did not correlate well with creep results.

Modification of the cell wall and not filling the lumen alone is required to affect MSE in bending creep.

The creep behaviour depends more of the material relation with wet and dry environment than the enhanced mechanicals strength imparted by modification on the wood material. The former are translated by the physical and mechanicals properties of the wood material, as ASE and SSE. The latter are translated by the increasing of compression strength and decreasing in tension strength, in general.

\section{References}

Bengtsson C. 2000. Creep of timber in different loading modes - material properties aspects. in The $7^{\text {th }}$ World Conference on Timber Engineering, August $12-15$, Shah Alam, Malaysia.

Bengtsson C. 2001. "Short-term" mechano-sorptive creep of well-defined spruce timber. Holz als Roh und Werkstoff, 59, 117-128.

Bollmus S., Dieste A., Militz H., Rademacher P. 2009. Properties of modified beechwood. Forst und Holz, 64 (7/8), 30-34.

DIN 52 185. 1976. Testing of wood: Compression test parallel to the grain. Deutsches Institut Für Normung e.V. Normen über Holz, Biegeversuch, Beuth, Berlin, September (in German).

DIN 52 186. 1978. Testing of wood; bending test. Deutsches Institut Für Normung e.V. Normen über Holz, Biegeversuch, Beuth, Berlin (in German).

DIN 52 188. 1979. Testing of wood: Determination of ultimate tensile stress parallel to grain. Deutsches Institut Für Normung e.V. Normen über Holz, Berlin, May (in German).

Dinwoodie J.M., Paxton B.H., Pierce C.B. 1981. Creep in Chipboard. Part 3: Initial Assessment of the Influence of Moisture Content and Level of Stressing on Rate of Creep and Time to Failure. Wood Science and Technology, 15, 125-144.

Dinwoodie J.M.W., Pierce C.B., Paxton B.H. 1984. Creep in chipboard. Part 4: The influence of temperature and moisture content on the creep behaviour of a range of boards at a single stress level. Wood Science and Technology, 18, 205-224.

Dinwoodie J.M., Higgins J.A., Paxton B.H., Robson D.J. 1990. Creep in chipboard. Part 7: Testing the efficacy of models on 7-10 years data and evaluating optimum period of prediction. Wood Science and Technology, 24, 181-189.

Dinwoodie J.M., Robson D.J., Paxton B.H., Higgins J.S. 1991a. Creep in chipboard. Part 8: The effect of steady-state moisture content, temperature and lev- 
el of stressing on the relative creep behaviour and creep modulus of a range of boards. Wood Science and Technology, 25, 225-238.

Dinwoodie J.M., Paxton B.H., Higgins J.-A., Robson D.J. 1991b. Creep in chipboard. Part 10: The effect of variable climate on the creep behaviour of a range of chipboards and one wafer board. Wood Science and Technology, 26 (1), 39-51.

Dinwoodie J.M., Higgins J.-A., Paxton B.H., Robson D.J. 1992. Creep in chipboard. Part 11: The effect of cyclic changes in moisture content and temperature on the creep behaviour of a range of boards at different levels of stressing. Wood Science and Technology, 26 (6), 429-448, DOI 10.1007/ BF00229247.

Donath S., Militz H., Mai C. 2004. Wood modification with alkoxys. Wood Science and Technology, 38, 555-566.

EN NP 408. 2003. Timber structures - Structural timber and glued laminated timber - Determination of some physical and mechanical properties. CEN Comité Européen de Normalisation, Bruxelles.

ENV 1156. 1999. Wood-based panels. Determination of duration of load and creep factors. CEN Comité Européen de Normalisation, Bruxelles.

Epmeier H. 2006. Moisture-related properties of modified timber - an experimental study. Ph.D. thesis, Chalmers tekniska högskola - Institutionen för byggoch miljöteknik, Chalmers, Sweden, N. serie, no. 2533.

Epmeier H., Westin M., Rapp A. 2004. Differently modified wood: Comparison of some selected properties. Scandinavian Journal of Forest Research, 19 (5), 31-37.

Epmeier H., Johansson M., Kliger R., Westin M. 2007. Bending creep performance of modified timber. Holz als Roh und Werkstoff, 65, 343-351.

Epmeier H., Kliger R. 2005. Experimental study of material properties of modified Scots pine. Holz als Roh- und Werkstoff, 63, 430-436.

Green D.W., Evans J.W. 2008. Effect of cyclic long-term temperature exposure on the bending strength of lumber. Wood and Fiber Science, 40 (2), 288-300.

Hanhijärvi A. 1999. Deformation properties of Finnish spruce and pine wood in tangential and radial directions in association to high temperature drying, part 2. Experimental results under constant condi- tions (visco elastic creep). Holz als Roh-und Werkstoff, 57, 365-372.

Hoffmeyer P., Davidson R.W. 1989. Mechano-sorptive creep mechanism of wood in compression and bending. Wood Science and Technology, 23 (3), 215-227.

Holzer S.M., Loferski J.R., Dillard D.A. 1989. A review of creep in wood: concepts relevant to develop longterm behaviour predictions for wood structures. Wood and Fiber Science, 21 (4), 376-392.

Homan W.J., Bongers F. 2004. Influence of up-scaling processes on degree and gradient of acetylation in Spruce and Beech. In: COST Action E22 (Hg.) Environmental Optimisation of Wood Protection. COST Action E22, Estoril, Portugal.

Hoyle R.J., Griffith M.C., Itani R.Y. 1985. Primary Creep in Douglas-Fir Beams of commercial size and quality. Wood and Fiber Science, 17 (3), 300-314.

Hunt D.G. 2004. The prediction of long-time viscoelastic creep from short-time data. Wood Science and Technology, 38, 479-492.

Hunt D.G., Shelton C.F. 1988. Longitudinal moistureshrinkage coefficients of softwood at

the mechano-sorptive creep limit. Wood Science and Technology, 23, 323-333.

Logsdon N.B. 1998. Influência da umidade nas propriedades de resistência e rigidez da madeira. Ph.D. thesis, Escola de Engenharia de São Carlos - Universidade de São Paulo, São Carlos-Brasil (in Portuguese).

Lopes D.B., Mai C., Militz H. 2012. Mechanical Properties and Creep Performances of Chemical Modified Portuguese Wood. In: Proceedings of the 6th European Conference on Wood Modification, Ljubljana (eds.: D. Jones, H. Militz, M. Petric, F. Pohleven, M. Humar and M. Pavlic), 55-62.

Morlier P. 1994. Creep in timber structures: report of RILEM Technical Committee 112-TSC, P. Morlier, London: Spon.

Mai C., Xie Y., Xiao Z., Bollmus S., Vetter G., Krause A., Militz H. 2007. Influence of the modification with different aldehyde-based agents on the tensile strength. In: The Third European Conference on Wood Modification, Bangor, UK (eds.: C.A.S Hill, D. Jones, H. Militz, G.A. Ormondroyd), 49-56.

Militz H. 1993. Treatment of timber with water soluble dimethylol resins to improve their dimensional sta- 
bility and durability. Wood Science and Technology, 27, 347-355.

Mohager S., Toratti T. 1993. Long term bending creep of wood in cyclic relative humidity. Wood Science and Technology, 27, 49-59.

Molinski W., Raczkowski J. 1988. Creep of wood in bending and non-symmetrical moistening. Holz als Roh- und Werkstoff, 46 (12), 457-460.

Norimoto M., Gril J., Rowell R.M. 1992. Rheological properties of chemically modified wood: relationship between dimensional and creep stability. Wood and Fiber Science, 24 (1), 25-35.

Pfeffer A.G. 2011. Effect of water glass, silane and DMDHEU treatment on the colonisation of wood by sapstaining fungi. Ph.D. thesis, Georg-AugustUniversitat Goettingen, Germany.

Instruction Manual Protimeter MMS Moisture Measurement System, 2005. INS5800A, October available 05-2011: http://www.ge-mcs.com/download/ sensing-manuals/MMS-Instruction.pdf.

Ranta-Maunus A., Kortesmaa M. 2000. Creep of timber during eight years in natural environments. World Conference on Timber Engineering. Whistler, CA, 31 July-3 August, available 07-2010: http://www. vtt.fi/inf/pdf/jurelinkit/RTE_Ranta-Maunus3.pdf.

Roszyk E. 2005. Effect of bending stresses on the wood creep in conditions of asymmetric changes in mois- ture content. Folia Forestalia Polonica, Series B, $36,15-26$.

Rowell R.M. 1996. Physical and mechanical properties of chemically modified wood. In: Chemical modification of lingocellulosic materials (ed.: R.M. Rowell), Marcel Dekker, New York, 295-310.

Santos J.A. 2009. Estudo de modelos e caracterização do comportamento mecânico da madeira. Ph.D. thesis, Universidade do Minho, Guimarães-Portugal (in Portuguese).

Schniewind A.P. 1967. Creep-rupture life of Douglas-fir under cyclic environmental conditions. Wood Science and Technology, 1 (4), 278-288.

Schniewind A.P. 1968 Recent progress in the study of the theology of wood. Wood Science and Technology, 2, 188-206.

Scholz G., Krause A., Militz H. 2009. Capillary water uptake and mechanical properties of wax soaked Scots pine. In: The Fourth European Conference on Wood Modification. 4th European Conference on Wood Modification, Stockholm (eds.: F. Englund, C.A.S. Hill, H. Militz, B.K. Segerholm), 209-212.

Xie Y., Krause A., Militz H., Turkulin H., Richter K., Mai C. 2007 Effect of treatments with 1,3-dimethylol-4,5-dihydroxyethyleneurea (DMDHEU) on the tensile properties of wood. Holzforschung, 61, 43-50. 